\title{
Status Report on Irradiation Capsules Containing Welded FeCrAl Specimens for Radiation Tolerance Evaluation
}

Approved for public release.

Distribution is unlimited.
Kevin G. Field

Richard H. Howard

February $26^{\text {th }}, 2016$ 


\title{
DOCUMENT AVAILABILITY
}

Reports produced after January 1, 1996, are generally available free via US Department of Energy (DOE) SciTech Connect.

Website http://www.osti.gov/scitech/

Reports produced before January 1, 1996, may be purchased by members of the public from the following source:

\author{
National Technical Information Service \\ 5285 Port Royal Road \\ Springfield, VA 22161 \\ Telephone 703-605-6000 (1-800-553-6847) \\ TDD 703-487-4639 \\ Fax 703-605-6900 \\ E-mail info@ntis.gov \\ Website http://www.ntis.gov/help/ordermethods.aspx
}

Reports are available to DOE employees, DOE contractors, Energy Technology Data Exchange representatives, and International Nuclear Information System representatives from the following source:

Office of Scientific and Technical Information

PO Box 62

Oak Ridge, TN 37831

Telephone 865-576-8401

Fax 865-576-5728

E-mail reports@osti.gov

Website http://www.osti.gov/contact.html

This report was prepared as an account of work sponsored by an agency of the United States Government. Neither the United States Government nor any agency thereof, nor any of their employees, makes any warranty, express or implied, or assumes any legal liability or responsibility for the accuracy, completeness, or usefulness of any information, apparatus, product, or process disclosed, or represents that its use would not infringe privately owned rights. Reference herein to any specific commercial product, process, or service by trade name, trademark, manufacturer, or otherwise, does not necessarily constitute or imply its endorsement, recommendation, or favoring by the United States Government or any agency thereof. The views and opinions of authors expressed herein do not necessarily state or reflect those of the United States Government or any agency thereof. 
Nuclear Energy Enabling Technologies (NEET): Reactor Materials

\section{Status Report on Irradiation Capsules Containing Welded FeCrAl Specimens for Radiation Tolerance Evaluation}

Kevin G. Field and Richard H. Howard

Date Published: February $26^{\text {th }}, 2016$

Prepared by

OAK RIDGE NATIONAL LABORATORY

Oak Ridge, TN 37831-6283

managed by

UT-BATTELLE, LLC

for the

US DEPARTMENT OF ENERGY

under contract DE-AC05-00OR22725 



\section{CONTENTS}

Page

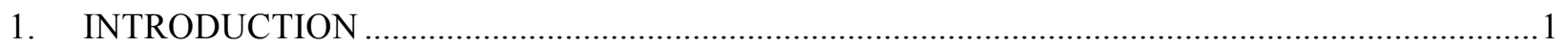

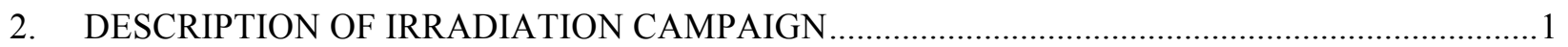

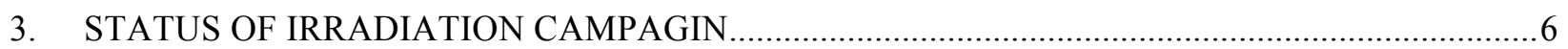

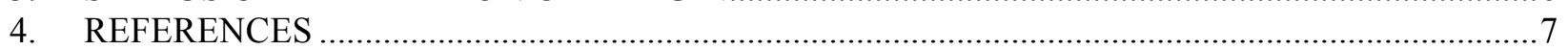

APPENDIX A: LOADING CARTOONS FOR LOW DOSE RABBITS …........................................ 


\section{INTRODUCTION}

This status report provides the background and current status of a series of irradiation capsules, or "rabbits", that were designed and built to test the contributions of microstructure, composition, damage dose, and irradiation temperature on the radiation tolerance of candidate $\mathrm{FeCrAl}$ alloys being developed to have enhanced weldability and radiation tolerance. These rabbits will also test the validity of using an ultra-miniature tensile specimen to assess the mechanical properties of irradiated $\mathrm{FeCrAl}$ base metal and weldments. All rabbits are to be irradiated in the High Flux Isotope Reactor (HFIR) at Oak Ridge National Laboratory (ORNL) to damage doses up to $\geq 15 \mathrm{dpa}$ at temperatures between $200-550^{\circ} \mathrm{C}$.

\section{DESCRIPTION OF IRRADIATION CAMPAIGN}

$\mathrm{FeCrAl}$ alloys are being considered for nuclear power production due to their excellent environmental compatibility in a range of different extreme exposures including liquid metal and aqueous corrosion [13]. Given this, a matter of concern based on the previous work done outside the nuclear field is the susceptibility of $\mathrm{FeCrAl}$ weldments and weld overlays to cracking using fusion-based welding techniques $[4,5]$. Furthermore, radiation can lead to a significant change in the overall microstructure in both the base metal and weldments leading to detrimental changes in the mechanical properties with increasing exposure. In order to assess the radiation tolerance of $\mathrm{FeCrAl}$ weldments in radiation environments and their susceptibility to cracking, a systematic irradiation campaign that uses a high-flux materials test reactor has been launched. Candidate $\mathrm{FeCrAl}$ alloys for the campaign were developed to both reduce the susceptibility of cracking in FeCrAl weldments and increase the radiation tolerance by doing careful modification of the composition and microstructure of the alloys [6-9].

The irradiation campaign has been designed to not only probe the radiation tolerance of different candidate alloys but also to understand the effects of irradiation temperature and damage dose. Three different irradiation temperatures were selected: $200^{\circ} \mathrm{C}, 330^{\circ} \mathrm{C}$, and $550^{\circ} \mathrm{C}$. Based on previous irradiation studies on $\mathrm{Fe}-\mathrm{Cr}$ based alloys, these three temperatures will probe three different regimes for the $\mathrm{FeCrAl}$ alloys: a dislocation loop dominated regime at $200^{\circ} \mathrm{C}$, a mixed dislocation loop and precipitation dominated regime at $330^{\circ} \mathrm{C}$, and softening or limited dislocation loop dominated regime at and above $550^{\circ} \mathrm{C}[10]$. The selected temperatures also span a wide range of temperatures seen within current fission reactor designs and possible future designs, hence providing critical data needed for the assessment of candidate welded $\mathrm{FeCrAl}$ alloys for a variety of nuclear power production applications.

Along with temperature, the irradiation campaign will also investigate the radiation tolerance of the $\mathrm{FeCrAl}$ alloys as a function of damage dose. Here, the nominal target doses were selected as 2 dpa, 8 dpa, and $15 \mathrm{dpa}$. This dose range spans a typical lifetime accumulated dose for a fuel cladding component. Also, doses above $\sim 15$ dpa will extend past the expected lifetime of the program and have much larger sample activities limiting possibilities for extensive post-irradiation examination efforts. Based on this design of experiment, the test matrix presented in Table 1 was developed. 
Table 1: Test matrix for irradiation within the HFIR. Nominal dose (dpa) is calculated based on a pure-Fe specimen.

\begin{tabular}{|l|l|c|c|c|c|c|}
\hline $\begin{array}{c}\text { HFIR } \\
\text { Position }\end{array}$ & $\begin{array}{c}\text { Capsule } \\
\text { ID }\end{array}$ & $\begin{array}{c}\text { Target } \\
\text { Temp } \\
\left({ }^{\circ} \mathbf{C}\right)\end{array}$ & $\begin{array}{c}\text { Number of } \\
\text { Cycles }\end{array}$ & $\begin{array}{c}\text { Nominal } \\
\text { Capsule Avg. } \\
\text { Flux }\left(\mathbf{n} / \mathbf{c m}^{2} \cdot \mathbf{s}\right)\end{array}$ & $\begin{array}{c}\text { Nominal Capsule } \\
\text { Avg. Fluence } \\
\left(\mathbf{n} / \mathbf{c m}^{2}\right)\end{array}$ & $\begin{array}{c}\text { Nominal } \\
\text { Capsule Average } \\
\text { Dose (dpa) }\end{array}$ \\
\hline \hline PTP D7 5 & FCAT01 & 200 & 1 & $1.10 \times 10^{15}$ & $2.81 \times 10^{21}$ & 1.9 \\
\hline PTP G4 5 & FCAT04 & 200 & 4 & $1.10 \times 10^{15}$ & $9.12 \times 10^{21}$ & 7.6 \\
\hline PTP G7 5 & FCAT07 & 200 & 8 & $1.10 \times 10^{15}$ & $1.79 \times 10^{22}$ & 15.2 \\
\hline PTP D7 6 & FCAT02 & 330 & 1 & $1.08 \times 10^{15}$ & $2.24 \times 10^{21}$ & 1.9 \\
\hline PTP G4 6 & FCAT05 & 330 & 4 & $1.08 \times 10^{15}$ & $8.96 \times 10^{21}$ & 7.4 \\
\hline PTP G7 6 & FCAT08 & 330 & 8 & $1.08 \times 10^{15}$ & $1.79 \times 10^{22}$ & 14.9 \\
\hline PTP D7 5 & FCAT03 & 550 & 1 & $1.10 \times 10^{15}$ & $2.81 \times 10^{21}$ & 1.9 \\
\hline PTP G4 5 & FCAT06 & 550 & 4 & $1.10 \times 10^{15}$ & $9.12 \times 10^{21}$ & 7.6 \\
\hline PTP G7 5 & FCAT09 & 550 & 8 & $1.10 \times 10^{15}$ & $1.79 \times 10^{22}$ & 15.2 \\
\hline
\end{tabular}

To reach the desired test temperatures and damage doses listed in Table 1 using the HFIR, small irradiation capsules, or "rabbits", are used which can house a varying range of different specimens including sub-sized tensile specimens. Two different tensile geometries were selected, one being a more "normal" SS-J type configuration and the recently developed SS-2E ultra-miniature tensile specimen. A schematic of the tensile specimens is shown in Figure 1. This irradiation campaign will be the first set of experiments assessing the validity of using SS-2E geometries to develop a mechanical properties database on irradiated FeCrAl base alloys and weldments. The SS-2E geometry is an attractive design to use as it significantly reduces the activated volume of a macro-scale tensile specimen with limited sacrifice in base mechanical properties $[6,7,9]$. As such, it provides greater flexibility in post-irradiation experiments and could garner more details on the deformation mechanics of irradiated FeCrAl alloys.
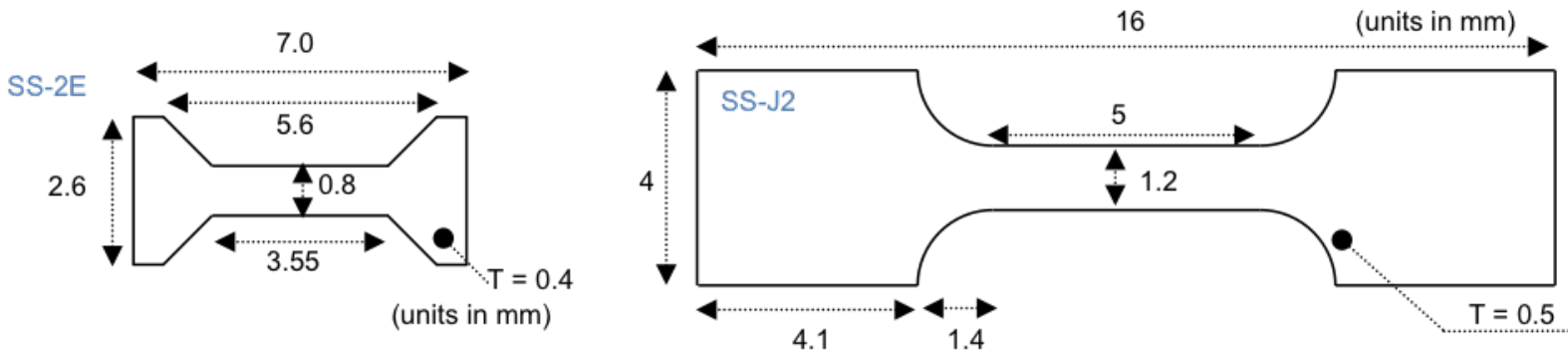

Figure 1: Simplified schematic of the tensile specimen geometries for weld and irradiation testing. Figure not to scale. Reproduced from Ref. [8].

The rabbits were designed in a way to optimize the number of SS-J type (27 specimens) and SS-2E (18 specimens) in a single configuration. The rabbits were also designed to include 12 (4 radially x 3 positions axially) passive $\mathrm{SiC}$ thermometry specimens to validate the modeled target irradiation temperatures. To ease post-irradiation examination and extraction of the specimens from the rabbits, samples were placed into three separate sub-housing or modules within the primary outer containment. A three-dimensional rendering of the design is provided in Figure 2. 


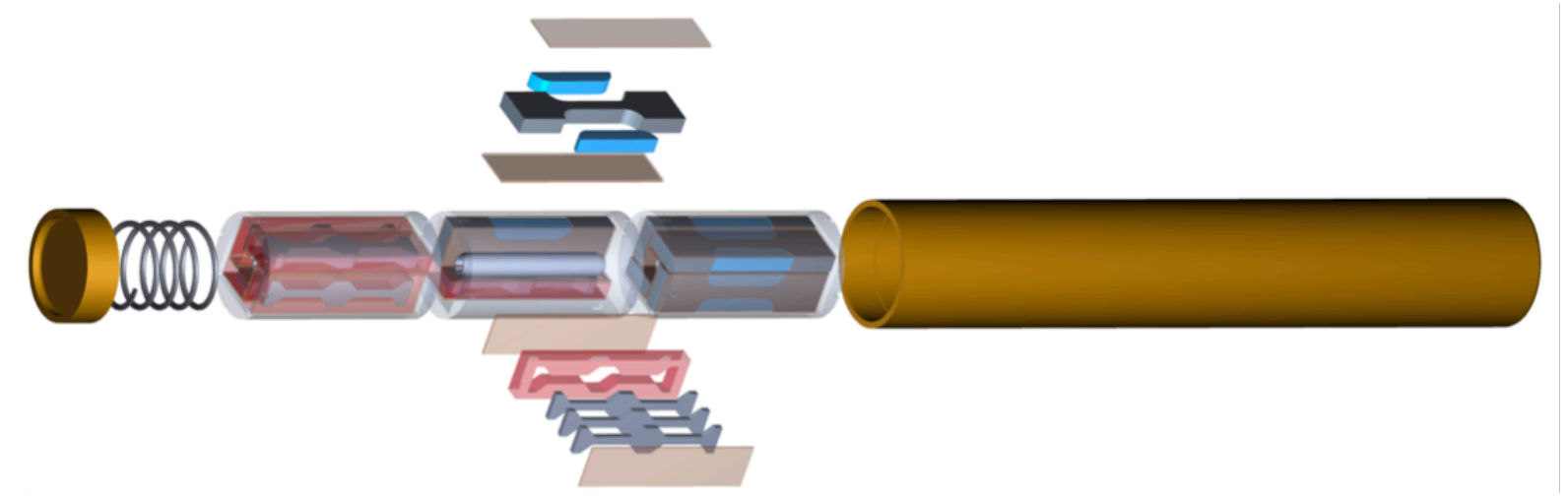

Figure 2: Finalized HFIR rabbit design for irradiation of welded and non-welded tensile specimens.

Temperature of the rabbit design selected in Table 1 is controlled by the axial location within the HFIR, the selected fill gas (typically $\mathrm{He}$ ), and the radial gap between the specimen holder (transparent geometries in Figure 2) and the outer housing. For this irradiation campaign, He was selected as the back fill gas while the axial positions provided in Table 1 for HFIR were selected as they reside near the HFIR core centerline resulting in limited variation in axial flux and hence minimizing thermal gradients axially. The result is the holder diameter (and material) was the primary variable for meeting the design temperatures in Table 1. The resulting modeled temperatures, associated HFIR positions, and holder diameters are provided in Table 2.

Table 2: Thermal analysis conditions for a mixed SS-2E and SS-J2 tensile specimens' rabbit.

\begin{tabular}{|c|c|c|c|c|c|c|}
\hline \multirow{2}{*}{$\begin{array}{c}\text { Target } \\
\text { Temperature }\end{array}$} & \multirow{2}{*}{$\begin{array}{c}\text { HFIR } \\
\text { Position }\end{array}$} & \multirow{2}{*}{$\begin{array}{c}\text { Holder } \\
\text { Diameter }\end{array}$} & \multirow{2}{*}{$\begin{array}{c}\text { Specimen } \\
\text { Location }\end{array}$} & \multicolumn{3}{|c|}{ Specimen Analysis Conditions } \\
\hline & & & & Avg. & Min. & Max. \\
\hline \multirow{3}{*}{$200^{\circ} \mathrm{C}$} & \multirow{3}{*}{ PTP 5} & \multirow{3}{*}{$9.43 \mathrm{~mm}$} & Outer & $199^{\circ} \mathrm{C}$ & $171^{\circ} \mathrm{C}$ & $242^{\circ} \mathrm{C}$ \\
\hline & & & Middle & $222^{\circ} \mathrm{C}$ & $177^{\circ} \mathrm{C}$ & $263^{\circ} \mathrm{C}$ \\
\hline & & & Inner & $235^{\circ} \mathrm{C}$ & $181^{\circ} \mathrm{C}$ & $277^{\circ} \mathrm{C}$ \\
\hline \multirow{3}{*}{$330^{\circ} \mathrm{C}$} & \multirow{3}{*}{ PTP 6} & \multirow{3}{*}{$9.28 \mathrm{~mm}$} & Outer & $314^{\circ} \mathrm{C}$ & $288^{\circ} \mathrm{C}$ & $351^{\circ} \mathrm{C}$ \\
\hline & & & Middle & $336^{\circ} \mathrm{C}$ & $292^{\circ} \mathrm{C}$ & $373^{\circ} \mathrm{C}$ \\
\hline & & & Inner & $348^{\circ} \mathrm{C}$ & $300^{\circ} \mathrm{C}$ & $386^{\circ} \mathrm{C}$ \\
\hline \multirow{3}{*}{$550^{\circ} \mathrm{C}$} & \multirow{3}{*}{ PTP 5} & \multirow{3}{*}{$9.00 \mathrm{~mm}$} & Outer & $502^{\circ} \mathrm{C}$ & $476^{\circ} \mathrm{C}$ & $543^{\circ} \mathrm{C}$ \\
\hline & & & Middle & $525^{\circ} \mathrm{C}$ & $484^{\circ} \mathrm{C}$ & $563^{\circ} \mathrm{C}$ \\
\hline & & & Inner & $537^{\circ} \mathrm{C}$ & $488^{\circ} \mathrm{C}$ & $575^{\circ} \mathrm{C}$ \\
\hline
\end{tabular}

The tensile specimens shown in Figure 1 and Figure 2 were fabricated from sheet feedstock of varying FeCrAl compositions and microstructures developed within this program. Details on the alloys have been described in greater detail and depth elsewhere [6,9]. Eighteen different unique sample configurations (alloy type, sample type, and welded or non-welded) were prepared for irradiation, see Table 3 for the single rabbit loading lists. It should be noted several alloys not of direct interest in this program are included to enable cross comparison of different alloy concepts and provide better scientific understanding of several different possible degradation mechanisms in the FeCrAl alloys. Here, only 2-3 tensile specimen types per specimen type are used in a single irradiation rabbit. This will allow for some repeatability in the data to be assessed. It is recognized that more samples would provide better statistics but a balance between assessing different specimens and statistics was struck in the current loading configurations. 
Table 3: Single rabbit loading list by alloy type, specimen type, and geometry. Alloys FCA-ODS and $\mathrm{C06M}$ are $\mathrm{FeCrAl}$ alloys currently of interest in other irradiation programs.

\begin{tabular}{|l|l|c|c|}
\hline $\begin{array}{c}\text { Material } \\
\text { Code }\end{array}$ & Condition & $\begin{array}{c}\text { Number of } \\
\text { SS-J2 per } \\
\text { rabbit }\end{array}$ & $\begin{array}{c}\text { Number of } \\
\text { SS-2E per } \\
\text { rabbit }\end{array}$ \\
\hline \hline C35M & non-welded & 3 & 2 \\
\hline C36M & non-welded & 3 & - \\
\hline C37M & non-welded & 3 & 2 \\
\hline C06M & non-welded & 3 & - \\
\hline FCA-ODS & non-welded & 2 & - \\
\hline C35MN & non-welded & 2 & 2 \\
\hline C35M10TC & non-welded & 3 & 2 \\
\hline C35M & welded & 2 & 3 \\
\hline C37M & welded & 2 & 2 \\
\hline C35MN & welded & 2 & 3 \\
\hline C35M10TC & welded & 2 & \\
\hline
\end{tabular}

All samples were manufactured from a single outside vendor in an effort to limit differences due to variances in manufacturing practices. After receiving the samples from the vendor, all samples were cleaned and visually inspected. Samples which did not meet the rigorous quality standards of the program were removed from the sample set for irradiation. Each sample was laser etched to provide a unique sample identity. Identification marks were placed on both tensile heads to keep traceability after fracture during mechanical testing. The laser marking scheme can be found in Table 4.

Table 4: Specimen ID marking for specimens for weld and irradiation testing

\begin{tabular}{|c|c|c|c|}
\hline $\begin{array}{c}\text { Spec } \\
\text { ID. }\end{array}$ & $\begin{array}{c}\text { Specimen } \\
\text { Type }\end{array}$ & $\begin{array}{c}\text { Material } \\
\text { Code }\end{array}$ & Condition \\
\hline \hline MFXX & SS-J2 & C35M & non-welded \\
\hline $\begin{array}{c}\text { MVXX } \\
6\end{array}$ & SS-J2 & C36M & non-welded \\
\hline MVXX & SS-J2 & C37M & non-welded \\
\hline THXX & SS-J2 & C35MTC10 & non-welded \\
\hline N5XX & SS-J2 & C35MN & non-welded \\
\hline FXX & SS-2E & C35M & non-welded \\
\hline IXX & SS-2E & C37M & non-welded \\
\hline HXX & SS-2E & C35M10TC & non-welded \\
\hline NXX & SS-2E & C35MN & non-welded \\
\hline
\end{tabular}

\begin{tabular}{|c|c|c|c|}
\hline $\begin{array}{c}\text { Spec } \\
\text { ID. }\end{array}$ & $\begin{array}{c}\text { Specimen } \\
\text { Type }\end{array}$ & $\begin{array}{c}\text { Material } \\
\text { Code }\end{array}$ & Condition \\
\hline \hline $\begin{array}{c}\text { MFXX } \\
\text { W }\end{array}$ & SS-J2 & C35M & welded \\
\hline VWXX & SS-J2 & C37M & welded \\
\hline NWXX & SS-J2 & C35MN & welded \\
\hline HWXX & SS-J2 & C35M10TC & welded \\
\hline AXX & SS-2E & C35M & welded \\
\hline BXX & SS-2E & C35MN & welded \\
\hline SXX & SS-2E & C37M & welded \\
\hline OXX & SS-2E & C35M10TC & welded \\
\hline
\end{tabular}

Prior to loading into the rabbits, care was taken to record the dimensions of each specimen including the gauge width and height to allow for proper calculation of tensile curves after irradiation. Samples were then loaded into the sub assemblies and outer housing. Images of the FCAT01 rabbit during sample loading are shown in Figure 3 and Figure 4. A cartoon was used to record the location of each specimen 
within the rabbit enabling cross-correlation between sample location and determined irradiation temperature in each sub-assembly. Final cartoons providing the location for the first three rabbits (FCAT01, FCAT02, and FCAT03) are provided in Appendix A. After loading, rabbits were initially sealed with a circumferential electron beam weld followed by leak testing to verify the quality of the weld. Rabbits were then back-filled with He and the weeping hole that allowed for gas communication and backfill into the rabbit was sealed using a pulsed laser beam weld. Final inspection included hydrostatic testing to ensure the overall quality of the welds and structural performance of the rabbit prior to insertion into the HFIR. Figure 5 shows the first three completed rabbits immediately prior to insertion in the HFIR core.

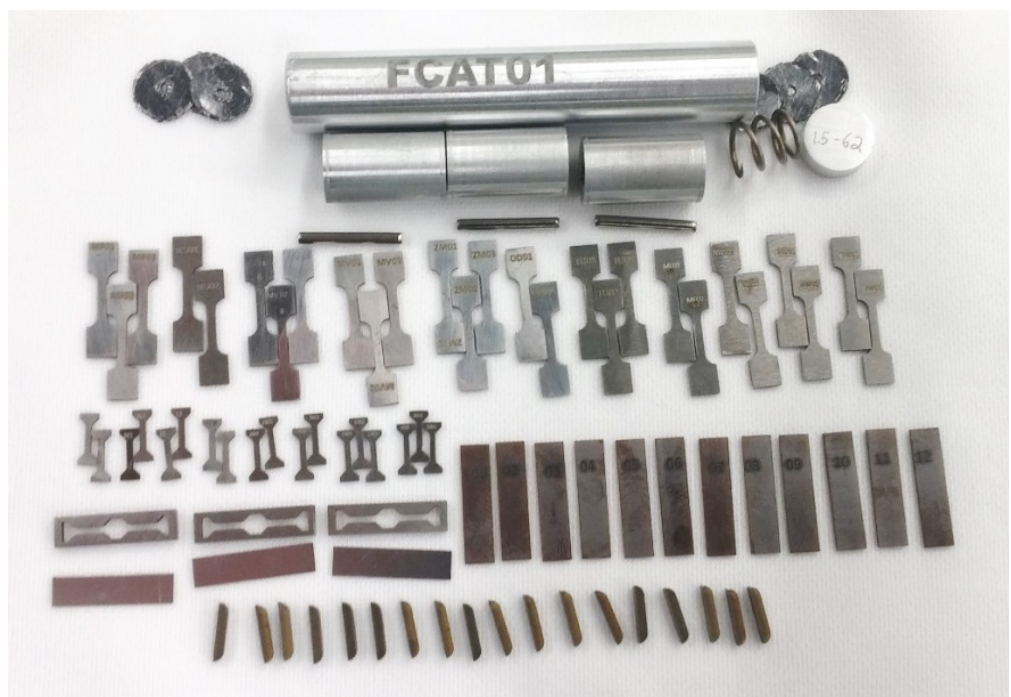

Figure 3: Internal components of the FCAT01 capsule during specimen loading.

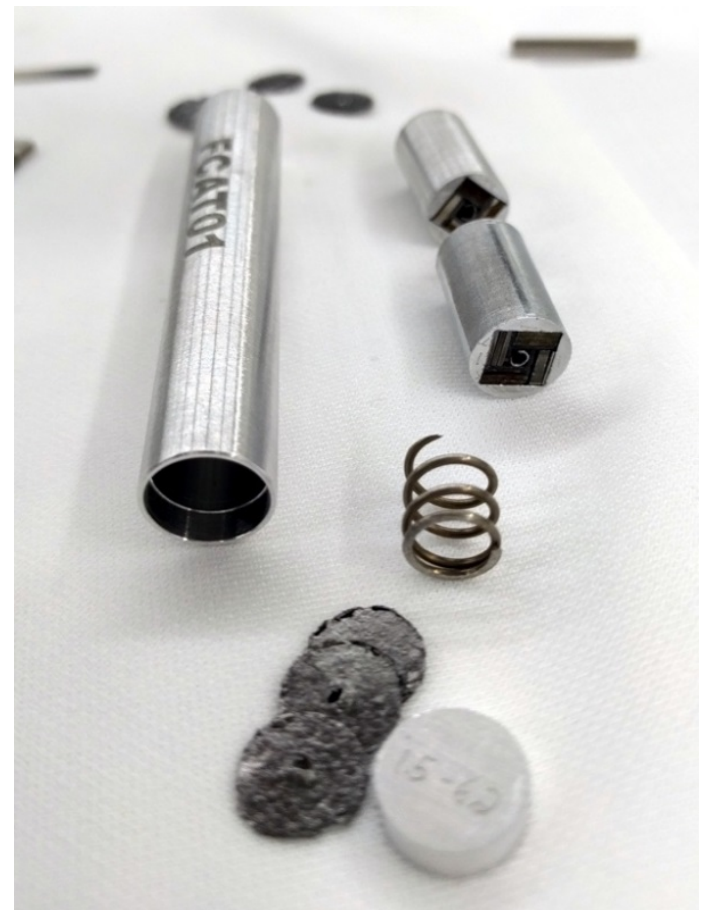

Figure 4: Photograph of the FCAT01 rabbit during specimen loading. 


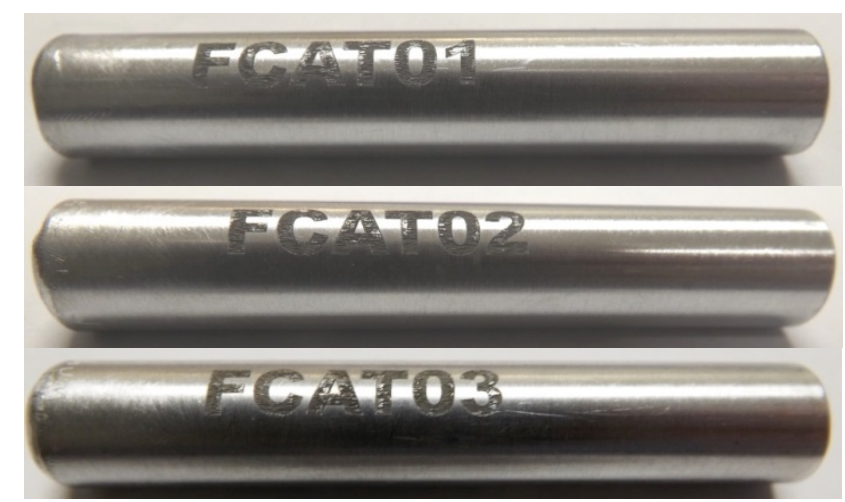

Figure 5: Photograph of completed rabbits prior to loading in the HFIR core.

\section{STATUS OF IRRADIATION CAMPAGIN}

The number of cycles required per rabbit for the desired fluence is provided in Table 1 . The first three rabbits (FCAT01, FCAT02, and FCAT03) were inserted in the HFIR core on February 12, 2016 and started irradiation at $85 \mathrm{MW}$ in cycle 465 on February 23, 2016. These three capsules will be irradiated for one cycle and be removed from the HFIR core on March 18, 2016 resulting in a total irradiation time of 24 days. Following irradiation, the capsules and corresponding samples will be held at HFIR for a period of approximately thirty days to allow for short-lived radioisotopes to decay and reduce the overall radiological threat of the capsules prior to shipment to the Irradiated Materials Examination and Testing (IMET) facility at ORNL. Therefore, post irradiation examination of the low dose capsules will begin in mid-April to May 2016. After capsule opening and sample sorting in IMET, specimens will be shipped to the Low Activation Materials Development and Analysis (LAMDA) facility for extensive mechanical and microstructural examination.

The remaining mid-dose and high-dose capsules (FCAT 04-09) will be inserted into the HFIR core during the cycle 465 outage scheduled to start on March 18, 2016 and finish on May 31, 2016. Irradiation of these capsules will begin starting on cycle 466 on May 31, 2016. The mid-dose capsules will be irradiated for four cycles and finish irradiation on December 16, 2016. The highest dose capsules will run for eight cycles, current HFIR operating schedule and forecasting does not provide details for the last two cycles, but is anticipated the samples will finish irradiation within the second quarter of the US fiscal year 2017. A breakdown of expected dates for all rabbits is provided in Table 5.

Table 5: Anticipated irradiation campaign schedule. Dates are approximant.

\begin{tabular}{|c|c|c|c|c|c|c|c|}
\hline $\begin{array}{c}\text { Capsule } \\
\text { ID }\end{array}$ & $\begin{array}{c}\text { Target } \\
\text { Temp } \\
\left({ }^{\circ} \mathbf{C}\right)\end{array}$ & $\begin{array}{c}\text { Number of } \\
\text { Cycles }\end{array}$ & $\begin{array}{c}\text { Average } \\
\text { Capsule } \\
\text { Dose (dpa) }\end{array}$ & $\begin{array}{c}\text { Capsule } \\
\text { Insertion } \\
\text { Date }\end{array}$ & $\begin{array}{c}\text { Capsule } \\
\text { Release Date }\end{array}$ & $\begin{array}{c}\text { Cycle Run } \\
\text { Numbers }\end{array}$ & $\begin{array}{c}\text { Shipment } \\
\text { Date to } \\
\text { IMET }\end{array}$ \\
\hline FCAT01 & 200 & 1 & 1.9 & $2 / 23 / 16$ & $3 / 18 / 16$ & 465 & $4 / 18 / 16$ \\
\hline FCAT04 & 200 & 4 & 7.6 & $5 / 31 / 16$ & $12 / 16 / 16$ & $466-469$ & $1 / 16 / 17$ \\
\hline FCAT07 & 200 & 8 & 15.2 & $5 / 31 / 16$ & TBD & $466-474$ & TBD \\
\hline FCAT02 & 330 & 1 & 1.9 & $2 / 23 / 16$ & $3 / 18 / 16$ & 465 & $4 / 18 / 16$ \\
\hline FCAT05 & 330 & 4 & 7.4 & $5 / 31 / 16$ & $12 / 16 / 16$ & $466-469$ & $1 / 16 / 17$ \\
\hline FCAT08 & 330 & 8 & 14.9 & $5 / 31 / 16$ & TBD & $466-474$ & TBD \\
\hline FCAT03 & 550 & 1 & 1.9 & $2 / 23 / 16$ & $3 / 18 / 16$ & 465 & $4 / 18 / 16$ \\
\hline FCAT06 & 550 & 4 & 7.6 & $5 / 31 / 16$ & $12 / 16 / 16$ & $466-469$ & $1 / 16 / 17$ \\
\hline FCAT09 & 550 & 8 & 15.2 & $5 / 31 / 16$ & TBD & $466-474$ & TBD \\
\hline
\end{tabular}




\section{REFERENCES}

[1] B.A. Pint, K.A. Terrani, M.P. Brady, T. Cheng, J.R. Keiser, High temperature oxidation of fuel cladding candidate materials in steam-hydrogen environments, J. Nucl. Mater. 440 (2013) 420 427. doi:10.1016/j.jnucmat.2013.05.047.

[2] K.A. Terrani, Y.J. Kim, B.A. Pint, Uniform Corrosion of Model FeCrAl Alloys in LWR Coolants, 2015 Am. Nucl. Soc. Annu. Meet. (2015).

[3] B.A. Pint, S. Dryepondt, K.A. Unocic, D.T. Hoelzer, Development of ODS FeCrAl for compatibility in fusion and fission energy applications, Jom. 66 (2014) 2458-2466. doi:10.1007/s11837-014-1200-z.

[4] J.N. Dupont, J.R. Regina, K. Adams, Improving the weldability of fecral weld overlay coatings, Foss. Energy Mater. Conf. (2007) 131-137.

[5] J.R. Regina, J.N. Dupont, A.R. Marder, The effect of chromium on the weldability and microstructure of Fe-Cr-Al weld cladding, Weld. J. 86 (2007) 170-178.

[6] K.G. Field, M.N. Gussev, Y. Yamamoto, X. Hu, R.H. Howard, Preliminary Studies on the Fabrication and Characterization of Fe-Cr-Al Alloys Designed to Have Enhanced Weldability and Radiation Tolerance, ORNL/TM-2015/192. (2015).

[7] K.G. Field, M.N. Gussev, X. Hu, Y. Yamamoto, Preliminary Results on FeCrAl Alloys in the Asreceived and Welded State Designed to Have Enhanced Weldability and Radiation Tolerance, ORNL/TM-2015/579. (2015).

[8] K.G. Field, R.H. Howard, Y. Yamamoto, Design of Experiment for Irradiation of Welded Candidate Fe-Cr-Al Alloys, ORNL/TM-2015/375. (2015).

[9] K.G. Field, M.N. Gussev, R. Howard, First Annual Progress Report on Radiation Tolerance of Controlled Fusion Welds in High Temperature Oxidation Resistant FeCrAl Alloys, ORNL/TM2015/770. (2015).

[10] A. Hishinuma, A. Kohyama, R. Klueh, D. Gelles, W. Dietz, K. Ehrlich, Current status and future R\&D for reduced-activation ferritic/martensitic steels, J. Nucl. Mater. 258-263 (1998) 193-204. 

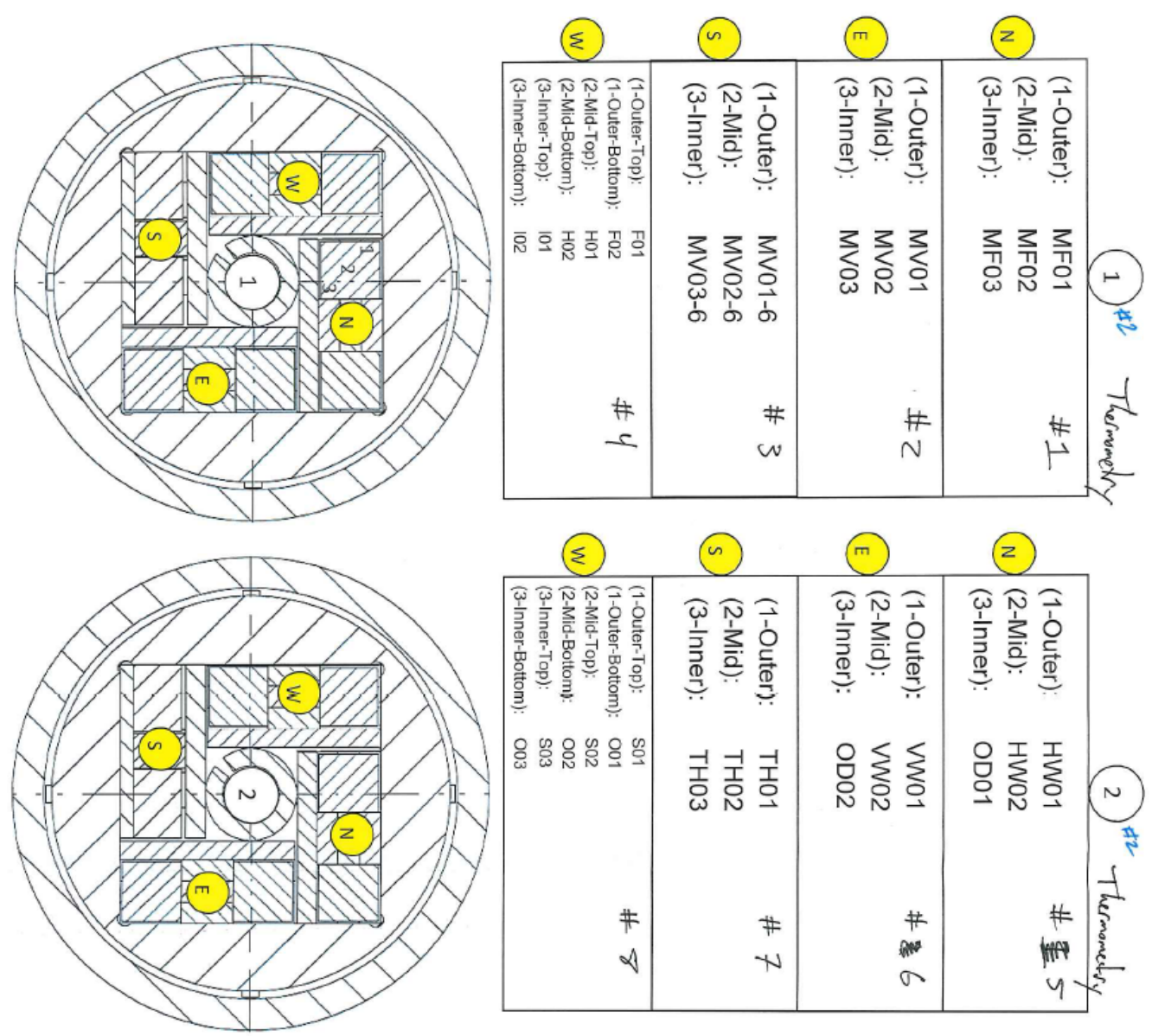

(s)

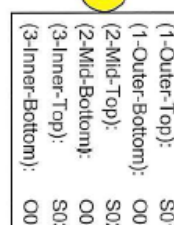

(a)

(m)

(2)
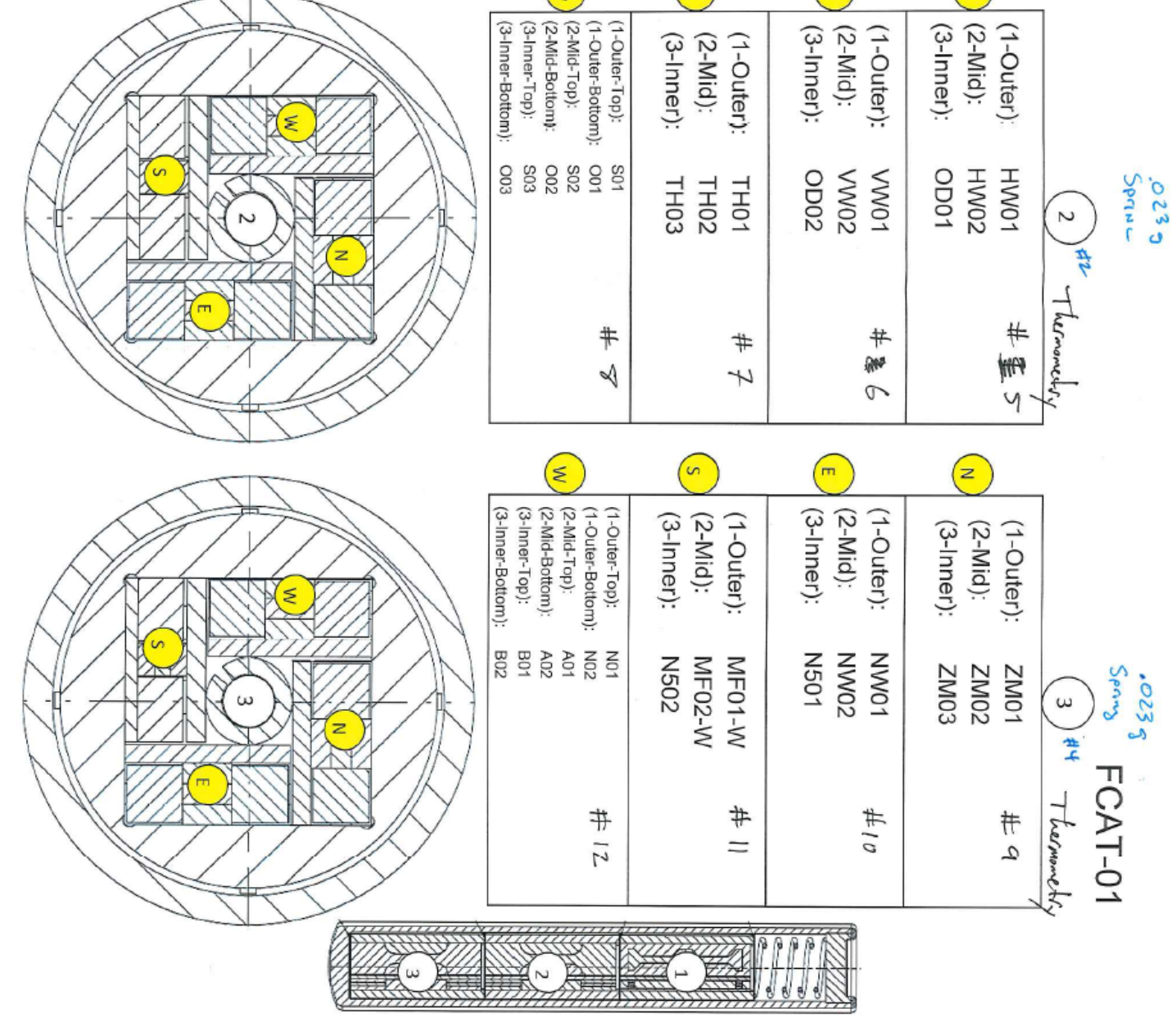

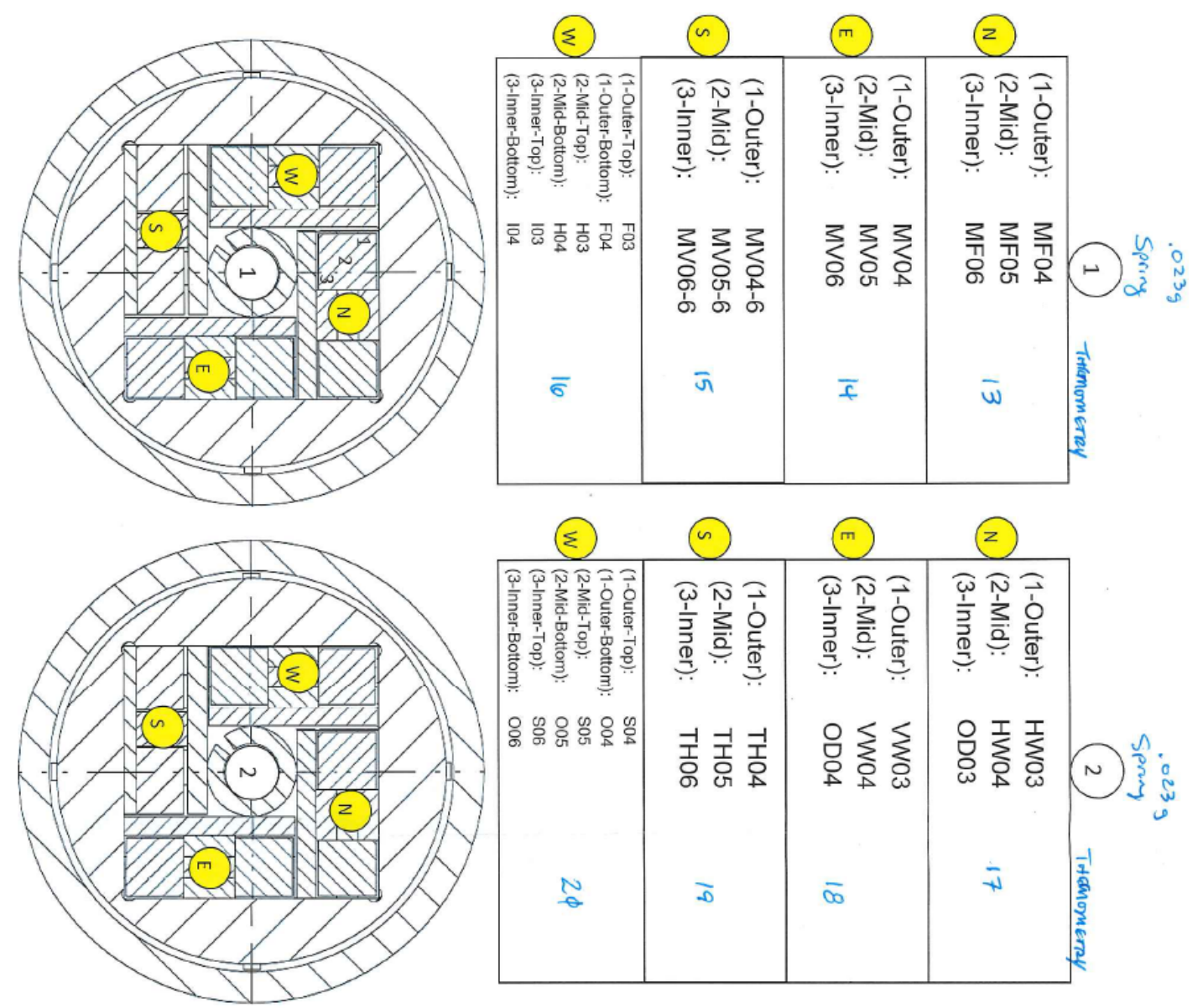

(ह)

(n)

(1)

(2)
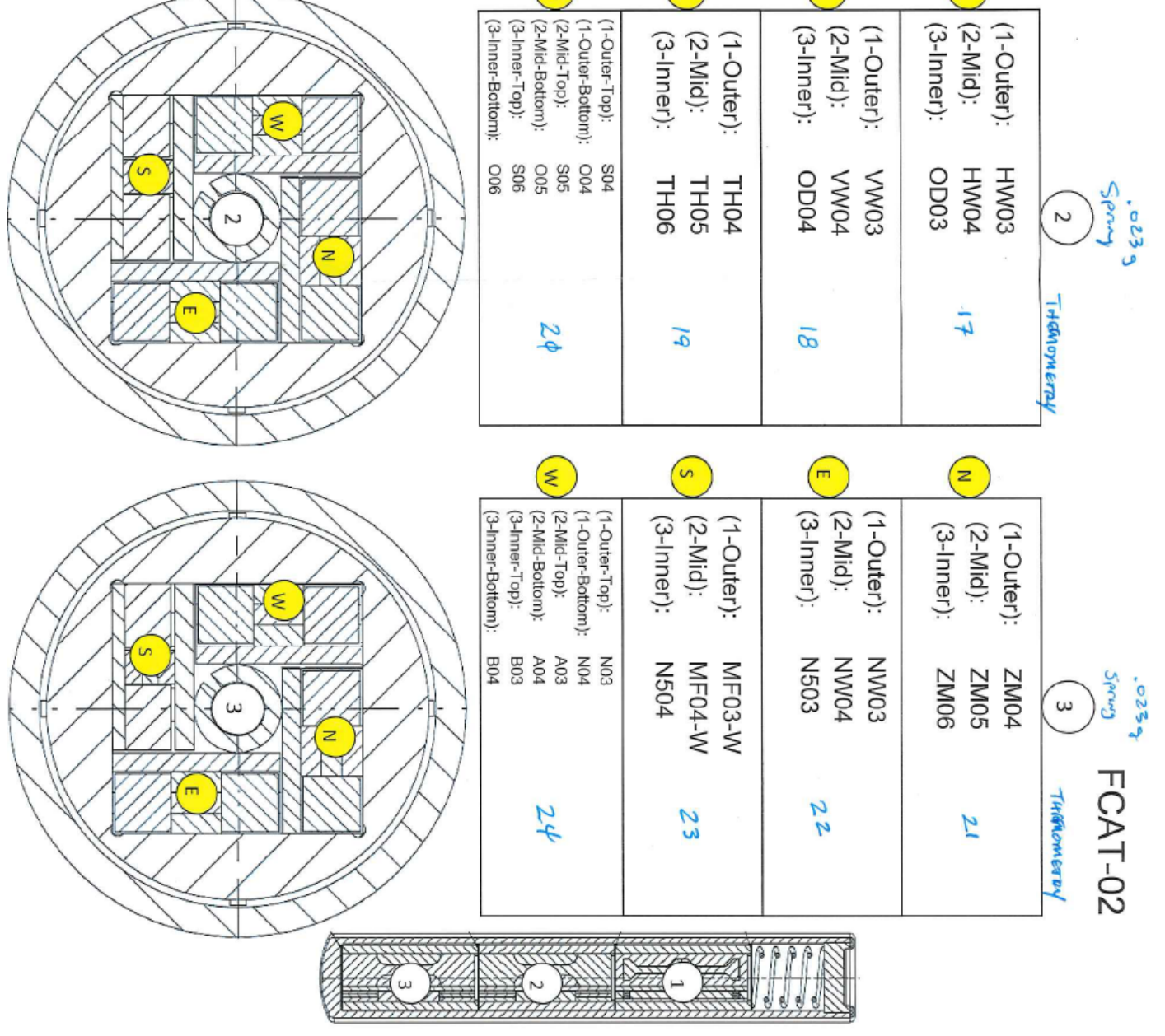

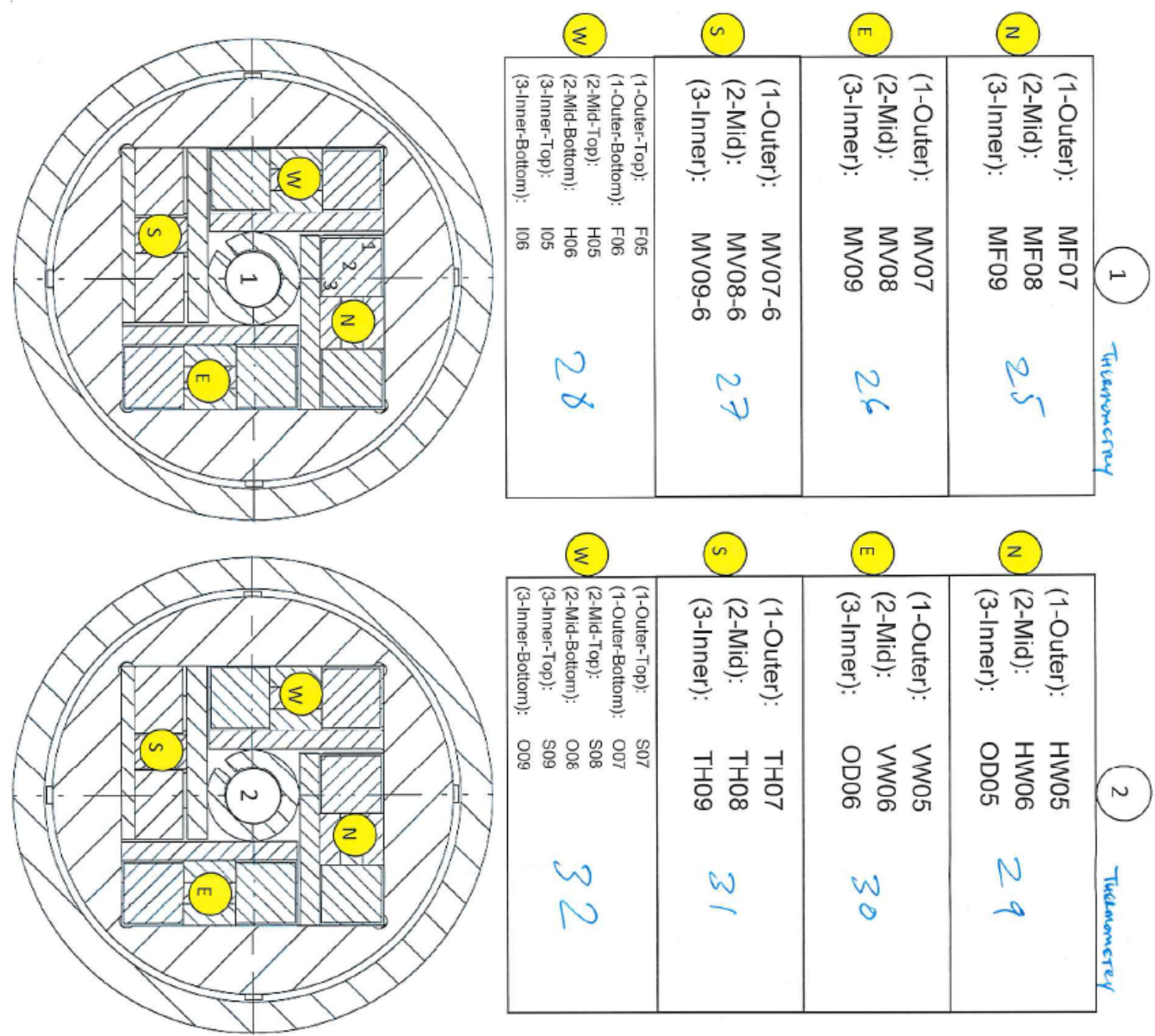

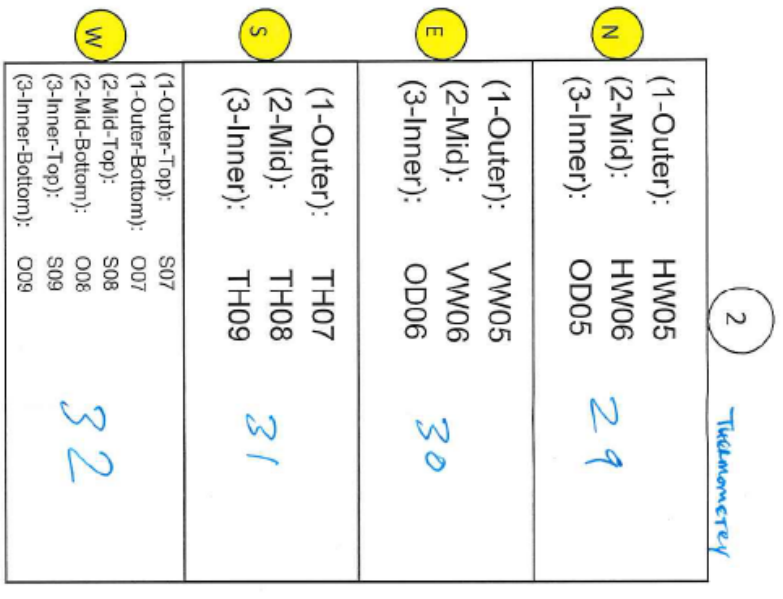

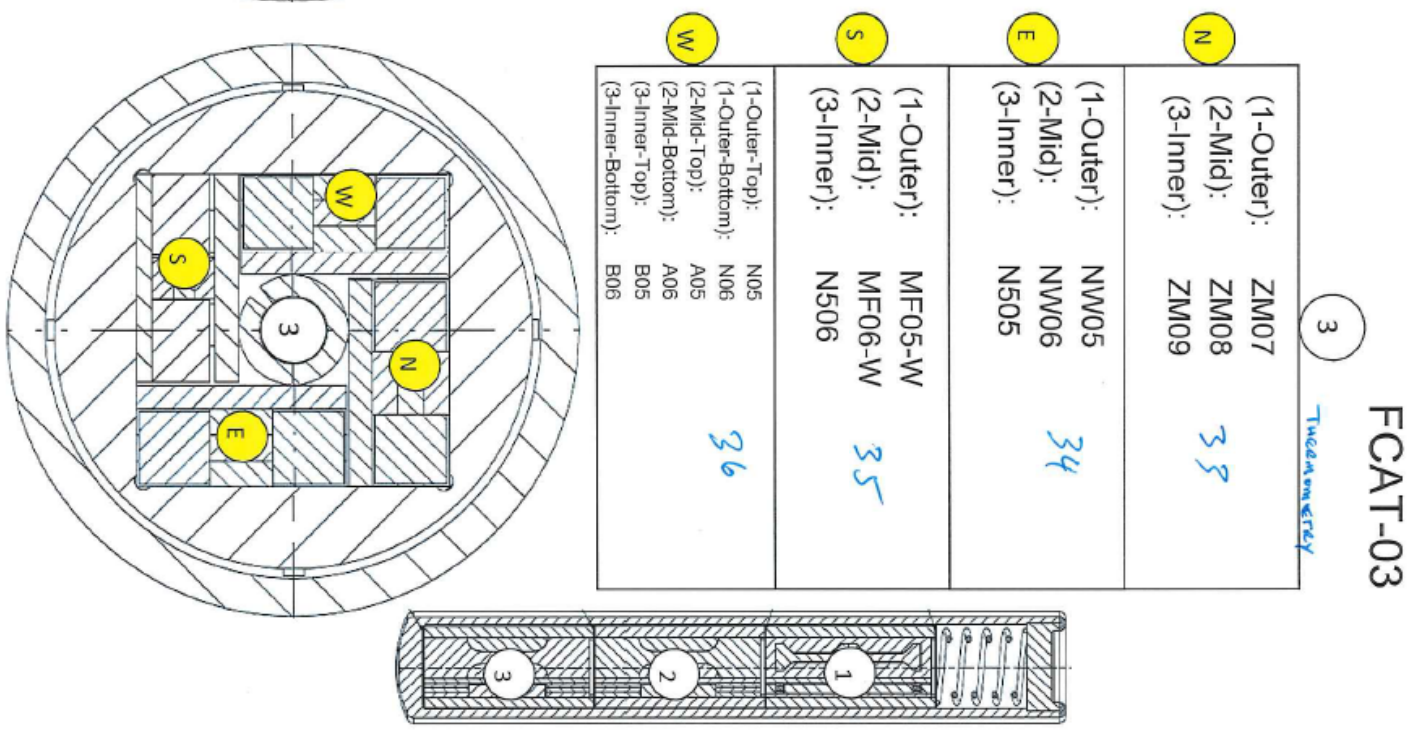

